\title{
The Genealogy of the Idea of Monarchy in the Post-Soviet Political Discourse of the Russian Orthodox Church
}

Translation by Jan Surer

Mikhail Suslov - Center for Russian and Eurasian Studies, Uppsala University (Sweden). mikhail.suslov@ucrs.uu.se

This article focuses on the concept of monarchy with an emphasis on the traditional Russian "autocratic" model. Mikhail Suslov inquires into the ways this concept is being used in today's Russian Orthodox Church and in the circles of religiously motivated intellectuals. Informed by the "contextualist" tradition in conceptual history, this article traces the concept of monarchy back to pre-revolutionary and émigré thinkers and argues that two understandings of the term have been evolving throughout Russia's modern history: the tradition of "divine kingship" (tsarebozhie), now largely marginalized, and the Slavophile interpretation that shifted substantially toward the idea of popular sovereignty and is now dominant in official and mainstream Orthodox political thought. The Slavophile concept of monarchy is internally contradictory and unstable, making its usage problematic, but, at the same time, it opens the possibility for new and original theorizing.

Keywords: Russian Orthodox Church, monarchy, monarchism, divine kingship, popular sovereignty, Slavophile, "Bases of the Social Conception."

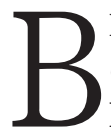

EFORE the fall of the monarchy in February 1917, the figure of the autocratic tsar was for many centuries the center of the Russian political world. Political theorists justified the monarchy and proposed measures to strengthen it, while the common people handed down from generation to generation the habits of the "language of monarchy" and "monarchist sentiments." Paradoxically, even early 2oth-century anti-monarchist discourse was bound up with an ingrained monarchism - indeed the very criticism of the monarchy 
often arose from the contrast between the actual tsar and the idealized image of a monarch. ${ }^{1}$ Conversely, at times intellectuals' conceptualization of the autocratic monarchy prompted them to acknowledge the necessity of radical reform and to refuse loyalty to the actual tsar in the name of realizing ideal autocracy (see Luk'ianov 2006: 54-59). The fact is that monarchism, and political traditionalism in general, resists rational interpretation and theoretical analysis. A monarchist has already lost his case as soon as he attempts to defend his political convictions by argument. In the monarchist's ideal world, such a situation could not even arise thanks to the "natural" and "self-evident" character of the monarchist system.

Precisely for this reason, in Russia, with its thousand-year experience of monarchy, monarchism as an ideology was paradoxically underdeveloped. This played a fatal role for the Romanov dynasty: the pre-revolutionary regime proved incapable of securing mass support amid the competitive politics of the early 2oth century. Some monarchists openly refused to deliberate on the topic of governance, asserting that autocracy in Russia concerned the realm of faith, mysticism and emotions and did not lend itself to analysis. Note the following statements by early 2oth-century commentators: in Vasily Rozanov's words, "Tsarist rule is a miracle" (Rozanov 1912). According to Nikolai Cherniaev, "Russian autocracy (...) [can] not but seem a supernatural matter, which is satisfactorily explained only through the participation of Providence in the fates of peoples" (Cherniaev 1998: 18). Sergei Bulgakov wrote that before his "conversion" to monarchism he "did not love the Tsar," for "the question of monarchy is, in essence, a question of love or non-love" (quoted in Kolonitskii 2010: 10).

Rationally arguing the impossibility of rational argumentation concerning the monarchy, these monarchists fell into the liar's paradox. Consequently, in pre-revolutionary Russia many intellectuals were convinced supporters of the monarchy, but few were monarchists. For example, the notorious Konstantin Pobedonostsev, whose rehabilitation in post-Soviet Russia has played a major role in the formation of contemporary conservatism, was undoubtedly a staunch monarchist, but his theoretical ruminations on monarchy were unoriginal and inconsequential for intellectual history. Other monarchist intellectuals

1. For the latest research devoted to the nuances of (anti-) monarchist consciousness, one can point to Kolonitskii 2010: 552-65. In an earlier period, monarchist mythology lay at the root of mass protest movements-and not only in Russia. See the rich literature on this, for example Field 1976 and Hobsbawm 1971. 
who tried to develop original monarchist theories came under suspicion of the authorities and sometimes also found themselves under arrest. To the authorities, even dissidents on the right were first and foremost dissidents.

The Orthodox Church, with its experience of cooperating with the monarchy throughout the history of Russian statehood, was always a reliable ally of the rulers. But by the end of the imperial period the relations between church and monarchy had become problematic. Criticism of "caesaropapism" - that is, the assimilation of the church as a branch of the state bureaucracy - resounded increasingly in church circles (see, for example, Hedda 2008: 153-75). At the same time, the inherited intellectual tradition of the sacralization of the monarchy contrasted all the more irresolvably with the processes of modernization. After the Manifesto of October 17, 1905 - the third point of which read, "[This manifesto] establishes as an inviolable rule that no law can come into force without the approval of the State Duma," thereby formally, at least, abolishing the autocratic power of the tsar - sacred kingship generally sounded like a joke or, at best, a legend from the distant past. Finally, the particular attempts to theorize autocratic power rationally that I will examine below created ideological tension between reality and the imagined ideal, effectively undermining the actually existing dynasty. Occupying the honorable first position in Uvarov's political formulation "Orthodoxy, Autocracy, Nationality," the Orthodox Church did not rush to the aid of the tottering dynasty in 1917. As is well known, soon after Nicholas II's abdication Church leaders hastened to express their joy at the liberation of the Church from state oversight and initiated the relevant revisions of doctrine and liturgy. These Church reformers included such churchmen as Archpriest Ioann Vostorgov, the author of "The Monarchist Catechism" of 1911 (see "The Resolution of the Moscow Council of Deans [blagochinnykh] [March 7, 1917]" in Babkin 2006: 193-95). And note also the resolution of the Church Council not to sing "Many Years" to the emperor and members of his family (Babkin 2006: 379), which signified that the Church silently supported the abolition of the monarchy in Russia. In fact, the position of the Orthodox clerical hierarchs regarding the monarchy was one of the most important factors in the desacralization of autocratic rule and the development of the revolutionary process in the spring and autumn of 1917.

In contemporary Russia, people often idealize the actual interaction between the Church and the monarchy in the pre-revolutionary period, while a folkloric (lubochnyi) image of tsarist rule enjoys pop- 
ularity among sizeable groups of the population. A recent poll conducted by the Russian Public Opinion Research Center (VTsIOM) in March 2013 showed that 24 percent of Russians have nothing against the idea of the restoration of the monarchy; an analogous survey in 2006 numbered potential monarchists at 19 percent. In the same period the number of opponents of monarchy has also increased insignificantly: from 66 percent in 2006 to 67 percent in 2013. Thus, we can speak of the stabilization of the number of monarchist sympathizers at a level of approximately one-fifth of the population ("Monarkhiia v Rossii” 2013).

At present, the weakness of political monarchism can be explained with recourse to several factors. First, there is the significant rupture with pre-revolutionary political thought and tradition. The systematic "purge" of monarchist elements from the country in the 1920 s led to the entire core of the Russian monarchist tradition continuing its existence in emigration. Divided into several branches and dynastic lines, the present representatives of the House of Romanov abroad are unknown in contemporary Russia and arouse little interest among the Russian population. The monarchist tradition in the Russian Orthodox Church (ROC) is not so much being restored as being created from scratch. Despite mass republication of pre-revolutionary monarchist theorists by nationalist and radical right-wing publishers, the current level of political discussion about autocracy remains quite low. The assimilation of monarchist ideology on the popular level goes no further than idiosyncratically understood and quite superficial ideas. Therefore, public discussion of the theory of monarchy rarely goes beyond the bounds of considering the historical achievements and aesthetic appeal of the pre-revolutionary empire. That is, monarchy is a marker of a specific worldview rather than the product of rationalistic theorizing and political planning. In the same way, at the institutional level as well monarchism has not thus far been represented by political parties and movements of allRussian scope. For instance, only in 2012 did the Ministry of Justice register the first Monarchist Party of the Russian Federation, headed by the Urals-based magnate Anton Bakov ("V Moskve uchrezdena" 2012).

Second, the monarchists' factionalism does not facilitate successful institutionalization. Already at the end of the Soviet period two main camps of monarchists came together: the "legitimists," who affirm that the Romanov dynasty continues to enjoy the right to the Russian throne, and the "assemblyists" (soborniki), who demand a 
decision on a candidate for monarch by universal vote, that is, an "assembly" (sobor). The legitimists are also not a monolithic movement, for varying dynastic reckonings and the legal systems of different countries permit the designation of several possible claimants. The Russian Monarchist Party, for example, supports the candidacy of Prince Karl Emich of Leiningen, who recently adopted Orthodoxy and took the name Nikolai Kirillovich. In the view of the "assemblyists," an Assembly of the Land (Pomestnyi zemskii sobor) should be called, and, like the Assembly of 1613, it should elect ("call," as adherents of this view prefer to say) a tsar, not restricting itself to one specific dynasty. Archbishop Gavriil (Chemodakov) of Montreal and Canada, for example, supports this position. (On contemporary monarchists, see, for example, "Russkie monarkhisty" 1996; Krylov 2013.)

Does all this mean that we should discount monarchism as a serious ideological force in contemporary Russia? Most likely, monarchism does in fact possess great potential for growth and emergence from the "gray zone" of political marginality in Russia against the background of disillusionment with liberal democracy and the current regime's "tightening of the screws." This article seeks to demonstrate that monarchism plays an important role in the political philosophy of Orthodox Christianity and also cannot be ignored in political debates outside the Church. One of the central theses of "The Bases of the Social Conception of the Russian Orthodox Church," ratified at the Bishops' Council of 2000 (points III.1-III.7), is devoted to this topic. In order to understand what significance present-day Orthodox intellectuals ascribe to monarchism, in this article I trace the ideological genealogy of monarchism in Russian political theory with the aid of a close reading of "The Bases of the Social Conception" (hereafter, "Bases") and the reconstruction of the intellectual context to which it relates.

A concept of ideology as the "decontestation" of political debate serves as this investigation's theoretical basis. This means the ability of ideology to fix the meaning of concepts that, outside an ideological system, are "essentially contested." For example, we do not understand what a person means by "freedom" until we have discovered in what ideological context the term is used, in other words, until we have determined whether this person supports the ideology of liberalism or socialism, for example. The concept of "monarchy" also means different things in different contexts: in the perception of liberal democracy "monarchy" has one meaning; in Russian traditional- 
ism, another. ${ }^{2}$ The concept of monarchy, however (as with any other essentially contested idea), possesses a complex internal structure and dynamic. Therefore, the investigation of the concept of monarchy involves two analytical strategies: contextualization (that is, the identification of the intellectual context that determines the meaning of monarchy at a definite moment in time ${ }^{3}$ ) and a morphological analysis of the concept.

The article's main thesis is that the ROC accepts principally the Slavophile interpretation of autocracy in its late imperial version. On the one hand, this is actually one of the most thoroughly developed monarchist doctrines known in Russia. On the other hand, it arose during the period of the monarchy's decline and as its intellectual "pillar." In that era, monarchist theory was "modernized" by the inclusion of elements of nationalism and the concept of popular sovereignty. But with that the understanding of monarchy became contradictory, for the question of the ultimate source of authority - the divine will or the people's will - remained suspended in air. The "archaeology" of monarchist thought in the ROC reveals that monarchism's cultural resources, in the form in which they are being developed in contemporary Russia, are not able to form a sufficiently firm foundation for ideological constructions, inasmuch as the present-day theory of monarchism cannot escape from Slavophile paradoxes.

\section{Is Monarchy Preferable in the Opinion of the ROC Leadership?}

Reliable sociological data does not yet exist on the extent of monarchist ideas among the clergy and laity of the ROC, but some scattered facts permit the assertion that these ideas find a much greater response within the Church than in the country on average (see Turunen 2007) ${ }^{4}$. Just what is the position of official Orthodoxy on this matter? A resolution of the Bishops' Council speaks of "the non-preferability to the Church of any state system, any of the existing political

2. The research methodology summarized above owes much to Freeden 1998.

3. The contextual approach was developed by the so-called Cambridge School of intellectual history. Of the members of this school, Quentin Skinner exerted the greatest influence on the present work. See Skinner 1969; Skinner 2002.

4. See also a small collection of interviews conducted with clergy for the portal www.regions.ru. Of six Orthodox priests, six supported monarchy, while at the same time not one of the Muslim and Jewish religious leaders supported monarchy ["Sviashchennosluzhiteli o monarkhicheskoi idee" (2012)].) 
philosophies and any specific social forces and their leaders, including those now in power" ("O vzaimootnosheniiakh Tserkvi s gosudarstvom" 1994). 5 "Bases" (III.7, paragraph 3) quotes this assertion, especially emphasizing that the ROC does not interfere with the people's free choice regarding the forms and methods of government, "or at least does not oppose their choice" (III.7, paragraph 1). Quite reasonably in the same section (III.7, paragraph 3), "Bases" notes that the "non-preferability" principle is linked to the Church's main concern lying "not [in] the external organization of the state, but [in] the condition of its members' hearts" (see Kirill [Gundiaev] 2008). Stressing that there is no "equal sign" between monarchism and Orthodoxy, commentator Alexander Arkhangelsky, in the pages of the Journal of the Moscow Patriarchate, expresses his view on the permissibility and conventionality of all forms of government "except for absolute totalitarianism and regimes hostile to humanity" " $\mathrm{XX}$ vek v istorii Rossii" 2010: 73). One can compare, too, the words of Arkady Maler: "The symphony of Church and state is possible in the most varied forms and with the most varied state systems, excluding the two extremes (...) which are tyranny and anarchy" (Maler 2012).

It would seem that with this it would be possible to put the matter to rest and close the topic of "monarchism in Orthodoxy." For the authors of "Bases," however, these reflections merely frame the section's central thesis (III.7), which establishes a hierarchy of the forms of state power: the era of the biblical judges (judgeship), monarchy and democracy. At first, under the judges, "the right to rule was effected not through coercion, but by force of authority; moreover, this authority was accompanied by divine sanction." Subsequently, "under monarchy, power remains God-given, but for its exercise it employs coercion rather than spiritual authority." Finally, contemporary democracies "do not seek divine approval of their governance" (III.7, paragraph 2).

In the next paragraph of "Bases" bold type sets apart the main idea: "One can by no means exclude the possibility of a spiritual renewal of society such that a religiously higher form of state structure

5. Patriarch Alexy II consistently supported the concept of "non-preferability." In addressing whether monarchy was a superior political system, he answered: "As far as the Church is concerned, there cannot be any everlasting, non-transitory national state arrangements" (Aleksii II [Ridiger] 1991: 4). In contrast, Metropolitan Kirill during that time had developed a largely positive view of monarchy, linking the upheavals of the 2oth century in Russia with the weakening of Orthodoxy and monarchism (Kirill [Gundiaev] 1993: 11). 
becomes natural" (III.7, paragraph 3). In this way, "Bases" acknowledges that different forms of state power have a different relation to religion and morality: some are "religiously higher," others less so. Naturally, the Church prefers the former to the latter, for the "religiously higher" forms offer greater opportunities for care for the "condition of hearts." But if the form of government depends on morality, then the Church cannot be indifferent to the form of government. In this sense monarchy is good not simply from the standpoint of its political functionality, but also because of its particular beneficence toward the religious needs of the population. This brings into doubt the thesis of "non-preferability" of this or that state system; its paradoxical inclusion in the very section that refutes it deliberately softens the rather strong impression left by the Church's decisive stand on the political question.

The ideas of the authors of "Bases" enjoy wide currency among ROC clerics. For example, as Archpriest Alexander Shargunov notes, "an Orthodox monarchy (...) secures the majority of people the most favorable conditions for salvation" (Aleksandr [Shargunov] 2008). In the context of recent political debates Archpriest Gennady Belovolov discussed a soul-saving Orthodox monarchy in the following way: "If an Orthodox Tsar were in power, is it possible to imagine that he would remain indifferent to the murder of his own loyal subjects in the womb?! I think that on the first day of his accession to the throne an Orthodox Sovereign would ban this outrage. (...) Or what Tsar would permit the giving over of his young subjects into a family overseas with a complete change of their faith and citizenship." Subsequently, in commentary on his own text, he clarified his position: "In a democracy they will make you fill your heart with Snickers, whereas in an Orthodox Tsardom you will have greater opportunity 'to occupy your heart with God"' (Gennadii [Belovolov] 2010).

The priest Dmitry Sverdlov (banned from service for five years from January 14, 2013) noted the internal contradiction of the position of "Bases" regarding monarchy: “The Bases of the Social Conception' (...) leaves an ambiguous impression when it touches on monarchy. For example, it says there that 'the Church accepts the relevant choice of the people,' when the topic concerns the 'forms and methods of government.' Yet, of all the possible forms of social structure, the document designates only monarchy, along with theocracy (...), as 'God-given.' (...) Such double-mindedness leaves a person of the Church wide latitude for dreaming precisely of monarchy" (Sverdlov 2012). But then again, opponents of monarchy, too, can refer to the same sections in 
"Bases" to support their position. For example, the journal Foma, approved by the Publishing Council of the ROC, holds a skeptical view of monarchy. In 2008 the journal organized a special forum, "Should an Orthodox Person Be a Monarchist?" to which one of the originators of "Bases," Professor Andrei Zubov, for example, contributed. Zubov asserted that "when a society begins to increase in its Christian self-consciousness, then with time monarchy becomes unnecessary. (...) Because people themselves can find their own paths as they walk before God" ("Dolzhen li pravoslavnyi chelovek byt' monarkhistom?" 2008). In other words, his position, based on an interpretation of the same "Bases," directly contradicts Archpriest Alexander Shargunov's position mentioned above.

Here one must note that the monarchist argumentation in "Bases" has nothing in common with constitutional law. The "juridical" terminology in "Bases" is indefinite and obscure: the work labels roughly the same entity as "social organization," "form and method of government," "form of rule," "ruling form," "form of state structure" (III.7). From the perspective of constitutional law, juxtaposing monarchy and democracy (III.7, paragraph 2) is as senseless as comparing apples and oranges, since they characterize different aspects of the state: a form of government (monarchy or republic) and a political system (rezhim) (democracy, authoritarianism, totalitarianism). A concept such as "judgeship" would perplex any legal expert. According to Konstantin Kostiuk, the conception of "judgeship" is a "valuable finding" in "Bases," since its utter unattainability and irrelevance "permits distancing oneself equally from all [actually existing] political forms" and thereby makes the thesis of "non-preferability" more persuasive (Kostiuk 2013: 364).

The point is this: Concerning monarchy, "Bases" is referring to a different intellectual tradition, one in which monarchy signifies exclusively the traditional Russian autocracy, whose foundations the document seeks in the biblical history of Israel's first kings. With this move the historically and geographically local phenomenon of the autocratic monarchy is elevated to the level of a universal model of "social organization." Nevertheless, the proposed hierarchy - judgeship, monarchy, democracy - still makes its classifications on varying principles, for it leaves significant gaps: for example, the European monarchies of the absolutist period, which "did not seek divine approval of their rule," were monarchies only on a symbolic level (that is, they were not monarchies from the perspective of "Bases"), yet nor were they democracies in any sense of that word. 
Be that as it may, "Bases" determined that from the religious perspective "monarchy" is preferable to "democracy," something that rightist intellectuals have not failed to notice. (See, for example, Semenko 2001 [2000]: 160.) One must understand the assertion of monarchy's preferability in the context of two other very important theses of "Bases." The first holds that the state and the Church have different "natures": "The Church was founded directly by God Himself (...) while the divine establishment of state rule reveals itself indirectly in the historical process" (III.3, paragraph 1). This interpretation imbues the Church's understanding of political phenomena, including its interpretation of monarchy, with great significance. Second, one of the most controversial moments in "Bases," immediately evoking friction with the authorities, is the recognition by the Church of the right "to refuse to submit to the state" if the latter compels believers to engage in sinful acts or to renounce their faith (III.5, paragraph 4). (Scholars have cited instances of the Kremlin's expression of dissatisfaction with the monarchist theses of "Bases." See, for example, Richters 2013: 24.) Taken together, these theses form the normative basis for oppositional activity by the ROC. With all the murkiness as to what constitutes sinful action and which actions will entice believers to renounce their faith, Church radicals can view virtually any state action as grounds for civil disobedience. Because of the existing dependence of the ROC on state structures, the expression of monarchist sympathies by the highest bishops of the Church cannot remain without consequences. Hence, both "Bases" and subsequent official political statements made by Church leaders soften the effect in the manner of "however, but then again (...)." Indeed, some of the literature notes that "Bases" was written in this style, which allows it to achieve a specific tactical compromise but to lose, from a strategic perspective, an opportunity for the development of theological ideas in Orthodoxy (Kostiuk 2013: 361 ; in his analysis Kostiuk refers to the work of Alexander Morozov [Morozov 2000]).

\section{The Two Bodies of the King: The Tradition of "Divine Kingship" Theology}

One can speak roughly of two traditional perceptions of "monarchy" in the ideology of Russian Orthodoxy. One of them closely links the Church and the autocracy, taking its cues from historical experience and the writings of the Church fathers. In contrast, the second sets forth the tradition of the Church's existence independent of the autoc- 
racy or even in spite of it. ${ }^{6}$ The political history of Byzantium and Russia offers an abundance of evidence for both viewpoints, in that periods of the monarchist state's support of the Church alternated with times of persecution (for example, the iconoclastic controversy in Byzantium) or complete subordination of the Church to the structures of power (the so-called "Synodal period" in imperial Russia).

A similar ambivalence is present in the biblical history of the first kings of Israel, lying at the root of the interpretation of monarchy in "Bases" and generally central to the Orthodox understanding of monarchy. Metropolitan Filaret (Drozdov) wrote in 1848: "The Creator (...) Himself raised up judges and leaders for this people, $\mathrm{He}$ Himself reigned over this kingdom (...) finally, He Himself instituted kings over them, and also continued the miraculous signs of His supreme rule over the kings." And further on he continues: "Perhaps, they say, all this was during the times of theocracy, that is, of divine rule, and now the times are different." In other words, for him there is no fundamental difference between the period of the prophets and the subsequent period of the kings; both one and the other fall into the same category of "theocracy," since later, too, during the government of the kings, divine rule over the people continued through God-given rulers. Needless to say, to him the transition to monarchy was not a "fall" or some sort of devolution. With an elaborate allusion to the Russian Empire, the metropolitan writes that in our time, too, nothing has really changed: "Has God actually ever abdicated His divine rule over the world and mankind, and particularly over those kingdoms and peoples in whom His spiritual kingdom has been predominantly realized and disseminated or that are especially aligned with His kingdom?” (Filaret [Drozdov] 1888 [1848]: 5). In his exposition, the history of King Saul's dethronement is entirely absent, and the discussion of the new period begins with King David (Filaret [Drozdov] 1888 [1848]: 10-11). He thereby avoids even the mention of a situation in which a monarchical ruler can lose divine sanction and, consequently, the throne. His history of the first kings of Israel centers on the moment of David's anointing to the kingship; moreover, Filaret emphasizes that this happened long before his actual accession to the throne. The explanation of this, in the theolo-

6. It is entirely possible to speak of two traditions in the relation of the Christian Church toward the state, one of which took shape as follows: "[T]he politically determined crucifixion of Christ, the persecution of the apostles and the first martyrs from the first days of Christianity's existence, established in Christianity the experience of alienation from and mistrust toward the state" (Kostiuk 2013: 17). 
gian's view, is that by divine dispensation David had to be elevated above the common people in order to become king, so as to highlight especially the transcendental approbation of his power independent of his personal feats (they became evident after his anointing) and the choice of the people.

Such an interpretation is standard for many traditional monarchies, including the Russian one, the theory of which, in comparison with the English monarchy of the Elizabethan period for example, was much more weakly developed from both the theological and juridical perspectives. The conception of authority propounded by Metropolitan Filaret shows not so much the uniqueness of the Russian "theology of rule" as its immaturity, for it differed little from that of the European Middle Ages. These theories shared the concept of "the two bodies of the king," according to which the person of the monarch consisted not only of his "earthly," physical nature, but also, through his anointing to the kingship, of a certain transcendental essence (Kantorowicz 1997: 47-87; see also Staats 1976). The latter made the earthly king into the "reflection" of Christ, a sacred, inviolable being, "God's anointed," to whom "we must submit not as to a person governing the people, but as to God himself" (Kovalevski 2011: 9).7

In medieval Russia, too, the idea of the divine basis of earthly rule and the character of the tsar's supremacy as the "living image" of its sacred prototype became established (Andreeva 2007: 193). This is the same idea as the medieval concept of "the two bodies of the king," as in the following: "The Christian ruler became the christomimetes literally the 'actor' or 'impersonator' of Christ - who on the terrestrial stage presented the living image of the two-natured God" (Kantorowicz 1997 [1957]: 47). According to Iosif Volotsky's interpretation, "The tsar in his nature is like unto all mankind, while in his rule he is like the most high God" (quoted in Andreeva 2007: 201). The foundational work of Michael Cherniavsky shows the evolution of the concept of the sacred ruler in medieval Rus. In his work Cherniavsky analyzes the way that from the dual image of the prince - "a saint on a throne" (that is, a passive passion-sufferer, an imitator of Christ, such as the saints Boris and Gleb, ${ }^{8}$ for example) and a "saintly prince" (that is, a

7. Giorgio Agamben expands upon Kantorowicz's analysis through the concept homo sacer. In his view, the representation of the person of the king stems from his historically established status as inviolable, existing beyond the bounds of any jurisdiction, and hence primarily political (see Agamben 2011).

8. Konstantin Kostiuk notes that princely saints were canonized "not with a view to their own merit as rulers but as passion-bearers" (Kostiuk 2013: 61). If I understand Kos- 
military leader and a martyr for the cause of Christ, such as Alexander Nevsky) - arose the conception of the God-given authority of the Orthodox tsar, who was not only "holy" himself, but who also represented the guarantee for the salvation of his people and state (Cherniavsky 1962: 22-23, 76). The theology of "divine kingship" suggested that kingly power in itself enjoyed divine origin and needed no special imprimatur from the Church (Andreeva 2007: 201).

As in medieval Western Europe, the concept of the tsar's sacred rule gave expression to the secular ruler's desire for autonomy from the Church. (Concerning this, see Figgis 1914, for example.) This explains in part the persistence of the tradition of the sacralization of authority in the 18th and 19th centuries, when cultural processes already in development tended toward secularization and the decree of 1680 banning the deification of the tsar continued in effect as well (Zhivov and Uspenskii 1987: 75; Baehr 1991: 27-29). In 1766, a new edition of the prayer service for the Sunday of Orthodoxy [the first Sunday in Lent - Editors], in use up to 1917, included the following among the anathematized by proclamation of the clergy in the name of the Church: "Against those who think that Orthodox rulers come to the throne not by special Divine favor toward them and who think that with the anointing to the kingship the gifts of the Holy Spirit are not poured out on them for the conduct of this lofty office; and therefore who dare to revolt and to commit treason against them: anathema" ("O chine pravoslaviia"). There is another comparatively late example: the regicide of March 1, 1881, which Orthodox and rightist, monarchist circles described in medieval terms as a martyr's death that atoned for the sins of the people and the state itself. For example, to Fr. John of Kronstadt, Alexander II "became a figure somewhat analogous to Christ, who died for the sins of the people and for the sake of salvation" (Kitsenko [Kizenko] 2006: 290). And note also the phrase: "the sacred blood of the Tsar-martyr" (Khoinatskii 1881: 2).

The anointing of the tsar in the Orthodox rite in Russia, as is wellknown, involved the union of two traditions: the anointing of the tsar to the kingship, characteristic of Byzantine and Western European

\footnotetext{
tiuk's thought correctly, then it is hardly possible to agree with it, for the princes were glorified as passion-bearers precisely because they were princes. A simple calculation performed by Michael Cherniavsky demonstrates that of 14 Kievan princes (from Vladimir Sviatoslavovich to Andrei Bogoliubsky) 10 were consecrated as saints; of 12 Muscovite rulers from the end of the fourteenth to the end of the sixteenth centuries seven were canonized, and the canonization of the eighth - Ivan the Terrible (Ivan Groznyi) is under discussion in society. Thus, in medieval Russia practically "all princes were seen as saints" (Cherniavsky 1962: 32).
} 
monarchical practice, and the sacrament of chrismation, performed in Russian Orthodoxy after baptism. The rite of anointing the tsar is analogous to the sacrament of chrismation - it symbolizes the second birth, thereby exalting the tsar over common mortals and declaring to him his special consecrated status. The communing of the tsar also over time began to resemble the Eucharist for priests, as if confirming the idea that the kingship and the priesthood "are the two greatest gifts," two positions of equally sacred significance (Zhivov and Uspenskii 1987: 24; Kostiuk 2013: 87-88).

Konstantin Kostiuk asserts that in contrast to the West the theology of authority developed in a contrary direction in medieval Russia toward the endowment of governance with sacred attributes and the erosion of the distinction between the "two cities." As a result, a spiritual mission and eschatological function were ascribed to tsarist rule, and the role of the people as a political agent was ignored (Kostiuk 2013: 108-9, 115). But in the 19th and early 20th centuries ideological searchings moved toward the revision of the traditional sacralization of authority. It is undeniable, however, that the traditional theology of "divine kingship" continued into the 2oth century as well, although it also ceased to be central to political theology. Accordingly, Sergei Bulgakov wrote, "The tsar bears his rule like the cross of Christ, and (...) submission to Him can also be through the cross of Christ and in His name" (quoted in Kolonitskii 2010: 10). In the same spirit, Kirill Zaitsev maintained that "only in terms of the Church's insight is it possible to understand who the tsar is. Only in God's Word is it possible to find the answer to the question of what the Russian Orthodox kingdom is" (Zaitsev 2010: 259).

That which was mainstream in medieval Russia and a traditionalist alternative to modernizing ideological projects at the end of the imperial period has, in present-day Russia, been pushed to the margins of political debate. Post-Soviet, radical-right Orthodox thinkers also support "divine kingship." For example, V. L. Kovalevsky writes that "the Russian Tsar was chosen to serve by God Himself. He was a messenger and servant of the Heavenly Father: a living weapon of the all-directing right hand of God, the executor of divine judgments." Vladimir Neviarovich asserts that "it is possible (and imperative) to regard Orthodox monarchy as an integral branch of Orthodox doctrine, sufficiently theologically developed and formulated by the fathers and learned men of the Church," the foundation of which was laid in the history of King Saul (Neviarovich 2004: 32). In his interpretation of this history, Neviarovich draws upon A. P. Lopukhin, a professor at the 
St. Petersburg Theological Academy, who argued that "during the time of the judges the whole life of the people - their religious-moral life as well as their political, social and family life - fell into disorder. (...) In the absence of a firm ruler to ensure the observance of the laws, morality (...) declined all the more" (Neviarovich 2004: 38; Lopukhin 1915: 64). According to this interpretation, not only was the establishment of the monarchy not a "fall," but it signaled a transition to a higher level of moral perfection in the life of the society (see Neviarovich 2004: 39). In contemporary monarchist literature, references to Archbishop Serafim (Sobolev), the author of the political treatise Russian Ideology, are also popular. In his treatise, Archbishop Serafim analyzes in detail the circumstances of Saul's anointing, refuting the view that kingly rule "was established as an indulgence." The archbishop writes that "through its desire to have monarchical rule" the people of Israel in no way "fell; they did not commit a sin. The word 'prizrekh' (1 Samuel 9:16) refers not to indulgence toward sin (...) but toward the [people's] sufferings and toward the establishment of kingly rule as a means for their salvation" (Serafim [Sobolev] 2002: 67-68). Serafim writes: "Christian monarchical rule received its genesis directly from God, the Heavenly King” (Serafim [Sobolev], Filaret [Drozdov], Ioann [Maksimovich] 2000: 87).

In the context of "divine kingship" theology one can consider also the radical-right currents among Orthodox intellectuals that develop the eschatological and messianic ideas of the Russian tsar as "one who holds at bay" (uderzhivaiushchii), that is, as a force of universal significance, saving the entire world from tumbling into hell (Aleksandr [Shargunov] 1999). It would be incorrect to suggest that attempts to revive the medieval theology of "divine kingship" are marginal in contemporary Orthodoxy; a whole series of influential religious media, including the radio network Radonezh and the news agency The Russian People's Service (Russkaia narodnaia liniia) support the monarchist line.

\section{Monarcho-Skepticism in the Russian Orthodox Church}

As we have seen, the position of "Bases" seriously differs from the theology of "divine kingship." First, "Bases" holds that "history's one true theocracy existed in ancient Israel before the period of the kings" (III.1, paragraph 3). Second, "Bases" clearly favors the view that "the Lord (...) regretted their [the people's] abandonment of divine rule" (III.1, paragraph 3), that is, he expressed regret specifically in connection 
with the change of government from that of "judgeship" to monarchy. Patriarch Kirill declares with the same certitude that under judgeship morality gradually declined, faith weakened and sinfulness increased among the people of Israel. Therefore the introduction of kingly power was "a deep spiritual tragedy" for ancient Israel, which rejected unmediated divine rule and placed over itself an earthly sovereign (Kirill [Gundiaev] 2013: 247-48).9

One also finds representation of the establishment of monarchy as a kind of decline, as the lowering of the moral level, in Orthodox thought at the end of the 19th and the beginning of the 20th centuries. For instance, Archbishop Andronik (Nikolsky) noted in 1907: "One must completely free oneself from that artificial, forced argument such as is typically made from the Holy Scriptures to confirm the exclusive correctness and perfection of only the strictly monarchist form of government. I implore every reader not to be alarmed (...) should I, a convinced tsarist, say definitely that there is no such evidence in the Holy Scriptures" (Andronik [Nikol'skii] 2004: 353). In his view, the prophet Samuel anointed Saul to the kingship only so that "the Jews would not forget God completely," and therefore monarchical rule was only "a protection and security against greater evils," and was not sacred (Andronik [Nikol'skii] 2004: 354-55).

This interpretation of monarchy was close to Nikolai Berdiaev's position, articulated in the pages of the journal The Way (Put'), in which a polemic arose concerning the interpretation of the story of Saul. Berdiaev objected to the notion of a biblical basis for monarchism and to the idea of a God-given king that A. Petrov and Grigory Trubetskoy supported (Petrov 1926: 134-39; Trubetskoi 1926: 172-75). According to Berdiaev, the Old Testament describes a conflict between theocratic and monarchist ideas, and therefore the power of the king was the result of moral decline and the people's opposition to living under a direct theocracy (Berdiaev 1926). The philosopher concluded that "monarchy (...) belongs entirely to this world, to the kingdom of Caesar, and its characteristics do not carry over to the Kingdom of God," and therefore there was no defining connection between Orthodoxy

9. Patriarch Kirill's position is shared by Archpriest Vsevolod Chaplin: "Even monarchy is perceived in this document ["The Bases of the Social Conception"] with regret, as a departure from divine rule” (Chaplin 2013). See also Archpriest Georgy Mitrofanov: "Monarchy, as with state systems [or "government"] in general, is the result of the Fall of the first people." ("Dolzhen li pravoslavnyi chelovek byt' monarkhistom?” 2008). Arkady Maler takes a similar view: "Therefore when the people demanded that the last judge, Samuel, give them a king (...) then the Lord was angry with his people (...) and the very establishment of the monarchy was a punishment for Israel” (Maler 2012). 
and monarchy (Berdiaev 1925: 31-32).10 The "Eurasianist" Nikolai Alekseev agreed with Berdiaev, affirming that monarchism was a pagan political concept, while true Christianity should avoid the heresy of "divine kingship" (Alekseev 1927).

This second way of thinking in the Orthodox theology of monarchy regards the idea of the tsar's godlikeness as heretical and blasphemous idolatry. In recent decades, the "liberal" camp of Church intellectuals continued the tradition of Berdiaev. For instance, Hegumen Veniamin (Valery Novik) agreed that the monarchist idea had pagan roots and declared that autocracy frees people from the burden of freedom and responsibility, just as the Grand Inquisitor proposes in Dostoevsky's novel The Brothers Karamazov (Veniamin [Valerii Novik] 1999: 274-75).

The same Bishops' Council that adopted "Bases" in the year 2000 also raised the question of the divine nature of tsarist rule in connection with the canonization of Nicholas II and members of his family. The matter evoked lively debates in society and the decision taken by the Council was something of a compromise between the positions of the rightists and those of the opponents of canonization. The former insisted on the recognition of the canonization of the tsar's family and their servants as martyrs, as the Russian Orthodox Church outside Russia (ROCOR) had done in 1981. As a result, the Council honored Nicholas II, the empress and their children as passion-sufferers. ${ }^{11}$ The difference between "passion-sufferers" and "martyrs" lies in this: a martyr can be merely a person who has suffered for his faith, while a passion-sufferer accepted a martyr's death in imitation of Christ. Furthermore, the Council specially emphasized that Nicholas II was canonized not as a tsar and not for his political activities nor ideologi-

10. Compare this with Sergei Bulgakov's assertion: "Although a certain theurgy is also inherent in the nature of tsarist rule, this did not displace nor substitute itself, however, for the natural, 'animal' principle of power. Tsarist rule still did not become theocratic through its theurgic aspect. (...) Inspiration by good, as well as by evil, remained equally possible for tsarist governance" (Bulgakov 1994 [1917]: 340). See also: "There is no dogmatic connection between Orthodoxy and a specific political system" (Bulgakov 2006).

11. In a report to the Bishops' Council the chair of the Synodal Commission on the Canonization of Saints, Metropolitan Yuvenaly (Poiarkov) analyzed in detail the arguments for and against the canonization of the imperial family and concluded that Emperor Nicholas II, Empress Alexandra, Tsarevich Alexey, and Grand Duchesses Olga, Tatiana, Maria and Anastasia underwent suffering and torment before their deaths. "It is in their understanding of this feat (...) that the Commission (...) finds it possible to honor in the Council these new martyrs and Russian believers with a place among the passionsufferers" (Iuvenalii [Poiarkov], Doklad). 
cal convictions, but as a private person. Finally, the Council specified that the canonization of Nicholas II did not signify the sanctification of monarchy in general (Russkaia Tserkov' na rubezhe vekov 2001: 14-18; Slater 2005; Bodin 2009). With all the historical equivocality of its decision the Council sought to supersede the medieval Orthodox tradition of the sacralization of rulers and simultaneously to obtain support from proponents of canonization on the right (and especially from ROCOR).

In 2009 the film Tsar, concerning the conflict between Tsar Ivan IV and Metropolitan Philip, came to the big screen, directed by Pavel Lungin. Oleg Yankovsky, who played the role of the metropolitan, received the blessing of Patriarch Alexy II, and the filming began with prayers to St. Philip. Theologian Alexander Dvorkin and Hieromonk Kosma (Afanasev) served as consultants for the film. The film elicited positive responses from representatives of the ROC and therefore can be regarded as expressing more or less the official position of the Moscow Patriarchate on the interrelation of the Church and tsardom in general. Two episodes in the film emphasize an extremely negative attitude toward Ivan the Terrible. In the first of these, the tsar is enticed to demonstrate his supposedly divine powers by calling down lightning, and lightning actually flashes forth, but the metropolitan declares that this power had not a divine but a diabolical source. ${ }^{12}$ The second episode, by contrast, depicts the metropolitan already in prison, when his fetters fall away miraculously and he discovers he has the gift of foreknowledge and of healing others through the laying on of hands. (For further details, see Halperin 2013.) Rating the film very highly, Protodeacon Andrei Kuraev found it significant that the film, which became something of an illustration of the mutual relations between tsar, Church, and people, came out several months after the enthronement of Patriarch Kirill: "Is it by chance or not, that the release of this film happened in the first year of the new patriarchate? Will it not fall to Patriarch Kirill to inherit not only St. Philip's throne but also his cross? Isn't this film a kind of spiritual bequest from St. Philip to Patriarch Kirill?” (Kuraev 2009a).

The film Tsar relates to the Orthodox theology of monarchy in many ways, including as an illustration of the idea expressed in "Bases" that the tsar can lose divine sanction. The story of Saul relayed

12. Compare this with Sergei Averintsev's evaluation of traditional autocracy in the context of the binary logic characteristic of Russian culture: "Autocratic rule is something residing either above the human world or below it, but in any case it seems not to be a part of this world" (Averintsev 1988: 220). 
in "Bases" shows that his authority passed to David without any regard for the dynastic principle. Moreover, in contrast to Metropolitan Filaret's interpretation, "Bases" pointedly emphasizes that David was the son of a simple man (III.1, paragraph 4) who nonetheless merited divine favor and was anointed to the kingship. In opposition to the views of radical-right intellectuals who want to canonize Ivan IV as "a Faithful Saint Tsar,"13 the film Tsar depicts Ivan the Terrible as a bloody tyrant. The film thereby reflects the position of the Church's highest bishops, in whose view "pseudo-zealots for Orthodoxy and autocracy (...) canonize tyrants and adventurists without authorization. No one knows whether these people do this deliberately or unconsciously. If deliberately, then they are provocateurs and enemies of the Church, who are trying to compromise the Church" (Aleksii II [Ridiger] 2001). 14

The film portrays Ivan the Terrible's moral bankruptcy and political failure and thereby lays the groundwork for criticism of the dynastic principle on the grounds that a person unfit for the role may come to the throne. Referring to current political events in Russia in 2009, Archpriest Dimitry Smirnov, then deputy chair and director of the administrative staff of the Patriarchal Commission on Family Matters and the Protection of Motherhood and Childhood, asserted that strong presidential rule with the transfer of power to a designated "successor" was better than monarchy, which offers no guarantee against accidents of birth (Russkii chas 2009). Metropolitan Hilarion (Alfeev) has spoken similarly: in his view monarchy is not the best form of government, for in history there have been various monarchs, some worthy and some not, and various presidents, but monarchy intrinsically does not preclude the transfer of power to an unworthy successor (Ilarion [Alfeev] 2013).

13. A recent initiative by supporters of the canonization of Ivan the Terrible was their demand to remove the painting by Ilia Repin, "Ivan the Terrible and His Son Ivan, November 16, 1581," from the halls of the Tretiakov Gallery on the basis that it is "vile, slanderous and false both in its subject matter and as a pictorial representation" and "offend[s] the patriotic feelings of the Russian people" ("Eta kartina oskorbliaet patrioticheskie chuvstva russkikh liudei" 2013). The communication to Minister of Culture Vladimir Medinsky was signed by Vasily Boiko-Veliky, Igor Froianov and the (former) priest Alexy Averianov.

14. Compare this with Patriarch Kirill's statement - "Tsar Ioann the Terrible (...) committed lawless deeds (...) a sea of blood was spilt in Rus" (Kirill [Gundiaev] 2010b: 96) and that of Metropolitan Hilarion (Alfeev) - "Ivan the Terrible (...) turned into a bloody tyrant who brought the country to socio-economic crisis" (Ilarion [Alfeev] 2010: 148). See also "K voprosu o kanonizatsii tsaria Ivana Groznogo i G. E. Rasputina,” 2008. 
Patriarch Kirill, despite his idealization of pre-Petrine Rus, also refrains from unequivocal support for autocracy. He has followed the canonical Slavophile theory about the harmony between tsar, patriarch and people in Muscovite Rus. The system of "checks" on tsarist rule included the authority of the Church, Church councils, Assemblies of the Land, and the practice of petitioning, in other words, the unmediated communication of the people with the tsar. For this reason the ancient Russian autocracy, according to Patriarch Kirill, did not resemble Western absolutism but came quite close to the ideal of "symphony" (Kirill [Gundiaev] 2010a: 250-51; 2010d: 83; 2010b: 95-96). At the same time, the Church's subordinate position during the Synodal period, when it became part of the state apparatus, has not been forgotten. ${ }^{15}$ Acknowledging the merits of autocracy in the past, Patriarch Kirill revises the formulation of "symphony" so that the concept of "monarchy" in it becomes the concept of "the state" in general. In particular, he has repeatedly affirmed that it is precisely today in post-Soviet Russia, and not in the pre-revolutionary period, that church-state relations have approached most closely to the ideal of "symphony," that is, the ideal of mutual non-interference in matters of the respective exclusive "jurisdictions" of the state and the Church and of mutual support in the remaining spheres (Kirill [Gundiaev] 2010a: 231). The topic of autocracy is often present in the discourses of Church leaders "apophatically," through its absence; for instance, speaking of the "calamities" that befell Russia after 1917, Patriarch Kirill mentioned "the grievous sin of apostasy committed by the entire people, (...) trampling on what is holy, (...) blasphemy and the mocking of the Church, of sacred relics, of faith" (Kirill [Gundiaev] 2010b: 57), but he did not refer to the fall of the monarchy and the execution of the imperial family.

\section{"The People Must Be Ready for Monarchy": Autocracy or Popular Rule?}

One can conclude from reading the story of Saul in "Bases" that the document injects elements of popular rule into the theory of Orthodox monarchy. "Bases" depicts the rise of the state as "God granting the people the opportunity to arrange their own social life based upon

15. See, for example: "The Church did not have an independent stance on social and political questions and could not, because it was part of the state apparatus" (Kirill [Gundiaev] 2010c: 29). See also Aleksii II (Ridiger) 2005: 214, 439. And Metropolitan Hilarion reminds us that the very restoration of the patriarchate became possible only after the fall of the monarchy (Ilarion [Alfeev] 2011: 166). 
the free expression of their will" (III.1, paragraph 4). Lungin's film also shows that the ultimate downfall for Ivan the Terrible was not divine punishment but the nonviolent opposition of his own people. The scene of the deposition of Metropolitan Philip shows the role of the Church in condemning the tsar's actions in the eyes of the people; the very last scene portrays the solitary tsar, waiting in vain for "his people" on a tsarist holiday.

The presence of this "democratic" element in Orthodox political theory is not at all self-evident, for it represents a departure from the canonical reading of tsarist rule as divinely established, with its source of legitimacy not in the will of the people but in the anointing of the tsar to the throne. The exposition of Saul's history in "Bases" once again leaves room for ambiguous interpretation: the establishment of monarchy was an act of divine indulgence (milost') toward the "free expression of the will" of the people, but in this reading what exactly is the source of this authority - divine indulgence or the will of the people - remains for the commentators to determine. All the same, the political language itself in "Bases" ("free expression of the will" and such like) shows how deeply the theory of popular sovereignty has penetrated into the Orthodox political tradition. Let us turn once more to the above-cited paragraph of "Bases" (III.7, paragraph 3): "One can by no means exclude the possibility of a spiritual renewal of society such that a religiously higher form of state structure becomes natural," but now let us focus on the concept of the "renewal of society." Then Metropolitan Kirill clarified this idea in a speech on March 27, 2007, in which he provided his own interpretation of the fall of the monarchy in 1917: "The moral state of the people no longer corresponded to the monarchist principle of state structure." In his view, monarchy "requires almost 100-percent religiosity among the people and society; the universal belief that the tsar is the anointed sovereign is essential." Raising the question of the possibility of monarchy amid the contemporary religious-moral state of Russian society, the future Patriarch Kirill remarked that if today monarchy were "by some miracle to be restored and if, God forbid, the tsar were to make some sort of mistake, they would throw tomatoes and rotten eggs at him just as they would at any feckless mayor" (Kirill [Gundiaev] 2007).

Commenting on Patriarch Kirill's speech, Andrei Kuraev connects the "monarchist principle" with the principle of Christian asceticism, of "self-diminishment," of "kenosis," arguing that under a monarchy the subjects must be prepared for unquestioning obedience, for "monarchy is the renunciation of one's own will and the entrusting of 
it to Divine Providence (...). People have to relax their clenched hands from the rude gestures to which they became accustomed during the years of co-rule and democracy into open palms, ready to receive everything that will issue from the throne as Divine Providence" (Kuraev 2009b: 390). But today, too, in Russia there is a "particle" of monarchy - the Moscow Patriarchate. "If our monarchists cannot take an oath to refrain from criticism of the Patriarch, how will they be able to keep themselves from criticizing a monarch?" (Kuraev 2009b: 39192). In sum, a good monarchist must be an Orthodox believer. Leaving aside the question of whether the converse is true or not, ${ }^{16}$ one can note that Andrei Kuraev also links monarchy with the formation of political agency in the (church-going) people. Many Church representatives hold the same view, that the people must be prepared for monarchy, and the degree of their integration into the life of the Church indicates this readiness. For example, Archpriest Maxim Kozlov, Archpriest Vladislav Sveshnikov, Archpriest Alexander Iliashenko, Archpriest Andrei Spiridonov, Archimandrite Platon Igumnov and others support this position. In these authors' works one can read such statements as these: "Monarchy can emerge when broad layers of society are found ready to acknowledge themselves as subjects of a sovereign"; "The chief prerequisite for the establishment of monarchy is moral and spiritual maturity and society's readiness to embrace it"; "One can raise the question of monarchy only if the people themselves truly feel that this is not forced upon them and is not the imposition of something alien"; "If it [society] wants to declare itself democratic, traditional monarchy is impossible"; "We simply have not grown up to this level [the establishment of a monarchy]; we still have not matured," and so forth ("Monarkhiia" 2012). There can be different readings of this matter: either the people are still not ready for monarchy or, as Archpriest Vsevolod Chaplin writes, the ideal of monarchy never "was lost" 17 among the people - but, in essence, the matter at issue here is one and the same, namely the inclusion of elements of the

16. The answer among the radical right to this question is unequivocally affirmative. See this quotation from Metropolitan Vladimir Bogoiavlensky: "A priest who is not a monarchist is not worthy of standing before the Holy Altar" (Neviarovich 2004: 21). See also the statement by Viacheslav Klykov: "A truly Orthodox person is first and foremost a monarchist" (Klykov 1996).

17. At a meeting with deputies from the Duma faction "United Russia" (Edinaia Rossiia) in May 2010, Vsevolod Chaplin declared that "the people must mature for monarchy"; and on November 3 that same year at an exhibit and forum entitled "Orthodox Rus" he called for the rectification of the "failure of legitimacy" of the existing system, a failure that came about because of the 1917 revolution (Malashenko and Filatov 2012: 63). 
theory of popular sovereignty at the very heart of Orthodox discourse on monarchy.

Contemporary "divine kingship," too, contains the same "democratic" element of the concept of "the renewal of society" but with the stress on nationalism. The representation of Nicholas II as a "redeemer" indirectly constructs a political subject, for the term "redemption" implies some sort of subject, a certain "we," who "are redeemed." The construction of "we" becomes still more prominently evident in that version of "divine kingship" that requires universal repentance for the sin of regicide, since the question "Who are the 'we' who must repent?" becomes unavoidable. The idea of repentance by the whole people thereby becomes an instrument for the nationalization of political discourse. Note Vladimir Neviarovich's statement: "Over each of us hangs the mortal sin of regicide. (...) First and foremost in this repentance is the recognition of oneself as one small part of the Russian people" (Neviarovich 2004: 262). Although the topic of collective repentance's political significance has been insufficiently researched in the literature (see for example, Celermajer 2009), it is possible to assert with sufficient conviction that the rituals and rhetoric of national repentance possess great potential for the formation of national identity. Within Russian culture, Alexander Solzhenitsyn has made the most influential statement of the link between the nation and collective repentance in his 1973 article, "Repentance and Self-Limitation as Aspects of National Life" (Solzhenitsyn 1995 [1973]). As one might expect, "repentance and self-limitation" are precisely the concepts most applied to contemporary discourse about the restoration of monarchy: repentance for the sin of regicide and "monarchical kenosis," mentioned above by Andrei Kuraev.

\section{The Slavophile Ideology of Autocracy}

One cannot say that the "democratic" element came into monarchist ideology only recently. On the contrary, the highest attainments of the Orthodox theology of secular authority were connected to the search for a political agent in the 19th and early 2oth centuries, first and foremost in the Slavophile tradition, in which the autocracy was significant insofar as it was an indication of the high spiritual condition of the peo- 
ple (D. Kh. [Khomiakov] 1903 [1899]: 40).18 To the classic Slavophile thinkers, the notion of autocracy did not exclude, but rather assumed, an element of popular rule in line with the sacramental formula, "the people opine, the tsar decides." A note by Archbishop of Perm Andronik [Nikolsky] in 1907 provides evidence of the penetration of Slavophile rhetoric into the Church milieu: "The autocracy, created in history by the people themselves and resting on the complete union of the Tsar with the people, the enduring expression of which was the Assemblies of the Land called by the Tsar as was the custom to take counsel with the realm, to hear the people's will - namely this was our unwritten constitution, according to which there is no Tsar without a people, nor a people without a Tsar: from the land comes counsel and will, while from the Tsar comes decision and rule" (Andronik [Nikolskii] 2004: 359). Slavophile thought contrasted such a union of tsar and people with the bureaucratic rule of absolute monarchies, as well as with the despotic government of a single individual and with parliamentary democracy.

The theological ideas of classical Slavophilism exerted an exceptionally powerful influence on the intellectual climate of the late imperial and émigré social-philosophical and theological debates and continue to resound in contemporary discussions. The concept of the Assembly of the Land, the idea that the people's will installed the Romanov dynasty on the throne through the Assembly of the Land of 1613, was central to Slavophile ideology (for example, see Koshelev 1862; Sharapov 1907). Later Slavophilism sought to develop more specific and juridically functional forms of "a people's monarchy," in which the people would possess not only "opinion" but also, to a certain degree, "decision." At issue was the concept of the integration of autocracy and local popular self-government; the publicist Sergei Sharapov (1855-1911) elaborated the most complete theory of such a state structure.

The concept of rule-of-law autocracy (pravovoe samoderzhavie) the idea that in contrast to despotism, Russian autocracy implied strict observance of the law - was one of the principal bases of the neoSlavophiles' theory. In the neo-Slavophiles' view, although the will of an unlimited monarch was the source of legislative authority, this in no way meant that his subjects had to endure arbitrariness and lawlessness (Vasil'ev 1883; Vasil'ev 1890: 70). First, as the jurist-theoreti-

18. Compare this with Konstantin Aksakov's statement: "We have had tsars who were impostors but no anointing oil for the impostor" (quoted in Slavianofil'stvo i zapadnichestvo 1991: 82). 
cians of tsarist Russia demonstrated, the laws approved by the monarch were binding on the tsar himself (of course, until such time as he desired to abrogate or change them). And second, the law-making process itself was also law-governed and followed a definite, sufficiently complex procedure rather than happening spontaneously upon the whim of the monarch (Korkunov 1892-93: 217-19).

A second and very important premise of neo-Slavophile analysis lay in the recognition of the people's legal capability, that is, the people's ability and opportunity to participate actively in political life and the adoption of decisions of state-level importance. Sharapov attempted to reconcile this premise with the concept of the tsar's unlimited rule, and developed the idea of two sources of authority - autocracy and self-rule. In his view, the authority of the autocrat had a divine origin and therefore was indivisible and non-transferable. In other words, it was laughable and blasphemous to think that the tsar could delegate part of his divine authority to a minister, and then the minister to a department head, and so on all the way down to the local constable. On this reading, only the tsar had complete authority, but how could this be when speaking of such a colossal and populous state as Russia? The tsar cannot interfere in every trifling case happening in the provinces, but neither can he delegate his authority to resolve the case "to the grassroots." This means that there must be a second source of authority, too - the people, who can, through a system of elections, delegate the resolution of their local matters at the levels of the township (volost'), county (uezd) and upward all the way to the central ministries (Sharapov 1905; Sharapov 1902). In practice this means that the tsar's prerogative relates to the most important state affairs, such as war and peace, the army and navy, railroads and finances, as well as oversight, while primarily local matters (education, policing, road building and so on) come under the purview of the people's representatives.

In 1905 an extensive essay by Lev Tikhomirov appeared entitled Monarchist Statehood, ${ }^{19}$ in which Tikhomirov grounded the possibility and desirability of autocracy at the most elementary, psychological level. He demonstrated that monarchy is psychologically very near to a person, since it embodies the authority of moral principle - univer-

19. Written in very weighty language, the book did not become a bestseller in monarchist circles. Archpriest Ioann Vostorgov took upon himself the role of popularizer of Tikhomirov's ideas; in 1911 he published his own work, The Monarchist Catechism, based upon Monarchist Statehood (Vostorgov 1995). 
sal for all people - over formal legal and bureaucratic norms. ${ }^{20}$ One can imagine such a perspective in the context of natural law theory. In the spirit of Thomism Tikhomirov brought natural law together with divine law: if people were perfect, then natural law would completely coincide with divine law, but after the Fall, the necessity for positive law arose; and positive law can differ greatly from divine law. In such a case, the essence of monarchy lies in establishing the union of divine and natural law and of overcoming the dominance of positive law. Tikhomirov rejected the concept of "symphony" at the institutional level and criticized the Byzantine tradition of the Church's subordination to state interests; he affirmed that the tsar and the Church should be united at another, more fundamental level, at the level of the human personality. At that level the Church's role consists of the instilling of religious morals, while the tsar's role is the expression of the people's moral ideals through political decision-making (Tikhomirov 1905).

The definitive crystallization of the "people's monarchy" concept takes place in Tikhomirov's works, for in contrast to the Slavophiles' theory, he - without entirely rejecting the divine nature of tsarist authority - interprets that authority in a circumscribed way and fuses it ultimately with the people's will (which in the last analysis is not surprising for a former member of the People's Will [Narodnaia Vol'ia]). The idea that the tsar expresses the people's moral ideal returns to the Church its key role as the guarantor of morality and religious salvation, a role taken from it by the sacred power of the tsar as understood in medieval theology. It was precisely for this reason that such an interpretation attracted support in post-Soviet political theology, with the groundwork laid by intellectuals from the religious and philosophical renaissance of the early 2oth century in both the Russian Empire and in emigration. For example, Nikolai Berdiaev wrote that under autocracy "the tsar and the people are linked to each other by one and the same faith, by one and the same submission to the Church and to God's truth. Autocracy presupposes a wide popular social base" (Berdiaev 1925: 33-34). The rite of coronation and anointing of the tsar was subjected to distinctive interpretation in this period. Sergei Bulgakov, for example, noted that through the rite

20. See, for example: "A monarchical supreme authority more effectively secures individual rights. (...) This conclusion derives from the fact that monarchy (...) is namely formed solely by the ethical principle" (Vereshchagin, Makeev and Ponezhin 2003: 56). Tikhomirov's ideas were taken up by Ivan Ilin. Cf., "True monarchy is realized only through the inner activity of the soul and spirit. It introduces into politics a principle of intimacy, devotion, warmth and heart-felt emotion" (Il'in 1979: 506). 
"a special, sacred-erotic bond is established with the people" (Bulgakov 1994 [1917]: 340). Note also the statement by Archpriest Ioann Vostorgov: "Here [in the anointing] the Tsar, crowned by God, enters into a holy sacramental union with his people" (Vostorgov 2011: 31). The metaphor of the state as a family, again coming to the surface of the political discourse in "Bases" (III.1, paragraph 2), has particular significance for monarchist consciousness, in which the image of the tsar mingles with the image of the "husband," and coronation to the throne with the sacrament of crowning the bride and groom (Ioann [Snychev] 2012 [1994]: 494).

In this intellectual tradition, dominant in Church discussions at the turn of the 2oth century, an understanding of the supernatural, divine nature of tsarist rule merges with the concept of popular sovereignty. Contemporaries commented upon the artificiality of such a combination. Vladimir Soloviev, and subsequently Pavel Florensky and Sergei Bulgakov, criticized the ideas of the Slavophiles, and of Alexey Khomiakov in particular, for their excessive devotion to "democratism" (Florenskii 1996 [1913]; on this see also Paromov 2011). In 1917 Sergei Bulgakov decried the "temptation of democracy" in Orthodox thought, alluding specifically to Slavophilism and populism with their tendency to deify the people and their faith in the "Father-Tsar (tsar-batiushka)"21 and to mix the sacred and the profane (Bulgakov 2009 [1917]: 30). Bulgakov noted that the Orthodox Church was a church of the common people, a people's church, and therefore for it the allure of democracy was especially strong in comparison with other Christian churches.

Despite this critique, the further "mainstream" development of Orthodox political thought was linked primarily to the Slavophile and populist tradition. The works of Ivan Ilin have exerted particular influence on the contemporary understanding of monarchy, including in Church circles; Ilin proposed a sort of synthesis of the neo-Slavophile "popular autocracy" and Tikhomirov's "natural law" with emphasis on the latter. Especially indicative of Tikhomirov's influence was the idea that the level of popular legal consciousness determines the form of state rule. (See, for example, Zernov 2007: 12.) It is specifically Ilin's formulation of the notion that "the restoration of the monarchy (...) is unthinkable without a simultaneous spiritual rebirth" of the Russian people that resurfaces in books by Metropolitan Ioann (Snychev) and other monarchists of our day (see Ioann [Snychev] 2011: 102). Ivan 
Solonevich's People's Monarchy (1973) is another source of inspiration for contemporary monarchists; to a significant degree it continues the Slavophile tradition of the nationalization of the theory of monarchy. In this theory, the monarch is necessary so that "the personal fate of individuals is knitted together into a single whole with the fate of the nation" (Solonevich 1991: 89).

\section{Conclusion}

In this article I have examined two main sources of theorizing about monarchy: the medieval concept of "divine kingship" and the modernizing Slavophile project of introducing elements of the theory of popular sovereignty into the understanding of monarchy. Although both traditions coexist in contemporary Russia, their proportion and the nature of their interaction have shifted toward the marginalization of "divine kingship." Having adopted "Bases," the leadership of the ROC made a decisive choice in favor of the Slavophile interpretation. First, the divine nature of governance in general and of the tsar's in particular was rejected. Second, monarchy was recognized as a less lofty form of government than "judgeship." Third, and this is key, the question of monarchy was transferred onto the social-ethical plane; monarchy was recognized to be morally more beneficial for the people and its restoration was considered possible provided that there was a "spiritual inspiration of society." The "people" were thereby recognized as a political agent, as the main beneficiary of monarchy and as its foundation.

Consequently, even while dreaming of pre-Petrine Rus and the "symphony" that allegedly existed in the 15th, 16th and 17th centuries, contemporary Orthodox monarchist intellectuals reconstruct not the concept of theological "divine kingship" that existed at that time, but rather the ideas characteristic of the final stage of the Russian monarchist tradition, which developed at the turn of the 2oth century. The neo-Slavophiles and conservative monarchists of the late imperial period expended their intellectual efforts toward the rational grounding and justification of the already tottering and "morally obsolescent" monarchy; these efforts therefore were necessarily contradictory. The attempt to reconcile the historically dying tradition of "divine kingship" with the idea of popular self-rule was not successful then during the pre-revolutionary years, and cannot be logically well-grounded in our day. That is, monarchism cannot stop short of the stage of the Slavophile conceptual mixture, and its proponents are compelled to 
take either a step "backward," toward "divine kingship," which means toward political marginalization, or "forward," toward a nationalist interpretation of monarchy.

The socio-political characteristics of traditional Russian Orthodox monarchy can be described by the concept of "empire," that is, as a "composite society," 22 a community of subjects of the tsar that was amorphous, heterogeneous, and exhibiting very weak - if they existed at all - internal bonds. Despite distinct attempts at "Russification" at the end of the 19th and the beginning of the 2oth centuries, "the nation" did not act in the capacity of a political end and self-sufficient entity, but rather served as a basis for loyalty to the autocracy (as in Sergei Uvarov's theory of "Official Nationality"). In the present circumstances, a community of subjects of a virtual tsar imagines itself with radically different traits - as a homogeneous, close-knit "people," drawn tightly together by "bonds" of Russian "national" belonging and Orthodox faith. Monarchy appears not as the cause but as the consequence of the existence of such a people. It is important to emphasize that the territorial bounds of the "Orthodox people" extend beyond the borders of the actual Russian Federation and are conceptualized by the notions of the "Russian World" (Russkii mir) and "Holy Rus," thereby announcing the potentially irredentist dimension of the imagined Russian monarchy.

Monarchy in its "non-autocratic," constitutional sense can also fit in quite well even in contemporary political debates tinged with nationalism as yet another instrument for the grafting together of the "nation" and as an important element in the ROC's new political language. In this manner, debates over monarchy serve as a unique intellectual proving ground for the Church in which the applicability of different traditions of political theology is tested and the working out of a new approach is proceeding - an approach that would emphasize the ideological self-sufficiency of the Church, that would be theologically sound and at the same time practically applicable as a program of political action.

\section{References}

"XX vek v istorii Rossii: Kruglyi stol." Zhurnal Moskovskoi patriarkhii ["The Twentieth Century in Russian History: A Roundtable." Journal of the Moscow Patriarchate] 2010 (2): $62-73$.

22. The journal Ab Imperio promotes the conceptualization of empire in terms of the notion of "composite society," and my use of the term here is influenced by its editors. 
Agamben, Giorgio. (2011). Homo Sacer: Suverennaia vlast'i golaia zhizn' [Sovereign Power and Bare Life]. Trans. from Italian. Moscow: Evropa.

Aleksandr (Shargunov). (1999). Pravoslavnaia monarkhiia i "novyi mirovoi poriadok" [Orthodox Monarchy and the "New World Order"]. Moscow: Novaia kniga.

-_-. (2008, November 15). "Otvety prot. Aleksandra Shargunova." Russkii dom ["Archpriest Aleksandr Shargunov Takes Questions.” Russian House], no. 11. [http://www. russdom.ru/node/101, accessed on August 15, 2014].

Alekseev, Nikolai N. (1927). "Khristianstvo i ideia monarkhii." Put' ["Christianity and the Idea of Monarchy." The Way] 6: 15-31.

Aleksii II (Ridiger). (1991). "Svet vo t’me: Interv'iu Patriarkha Aleksiia II ot 6 aprelia 1991 g." Zhurnal Moskovskoi patriarkhii ["Light in the Darkness: An Interview with Patriarch Aleksii II on April 6, 1991." Journal of the Moscow Patriarchate] 7: 2-5.

--_. (2001, December 15). "O popytakh psevdorevnitelei Pravoslaviia samochinno kanonizirovat' tiranov i avantiuristov." Pravoslavie i mir ["On Attempts by Pseudo-Zealots for Orthodoxy to Canonize Tyrants and Adventurists without Authorization." Orthodoxy and the World]. [http://lib.pravmir.ru/library/readbook/1188, accessed on August 15, 2014].

-_-. (2005). “Tserkov' i dukhovnoe vozrozhdenie Rossii." In Aleksii II, Slova, rechi, poslaniia, obrashcheniia, 200o-2004. T. 3. Ch. 2 ["The Church and the Spiritual Regeneration of Russia." In Sermons, Speeches, Pastoral Letters, and Addresses, 200O-2004. Vol. 3. Part 2]. Moscow: Moskovskaia patriarkhiia.

Andreeva, Larisa A. (2007). Sakralizatsiia vlasti v istorii khristianskoi tsivilizatsii [The Sacralization of Authority in the History of Christian Civilization]. Moscow: Ladomir.

Andronik (Nikol'skii). (2004). Tvoreniia: Stat'i i zametki. Kn. 1 [Works: Articles and Papers. Book 1]. Tver: Bulat.

Averintsev, S. S. (1988). "Vizantiia i Rus': Dva tipa dukhovnosti." Novyi mir ["Byzantium and Rus': Two Types of Spiritual Culture." New World] 7: 210-20.

Babkin, M. A. (Ed.). (2006). Rossiiskoe dukhovenstvo i sverzhenie monarkhii $v 1917 \mathrm{~g}$.: Materialy i arkhivnye dokumenty [The Russian Clergy and the Fall of the Monarchy in 1917: Materials and Archival Documents]. Moscow: Indrik.

Baehr, Stephen. (1991). The Paradise Myth in Eighteenth-Century Russia: Utopian Patterns in Early Secular Russian Literature and Culture. Stanford: Stanford University Press.

Berdiaev, Nikolai A. (1925). "Tsarstvo Bozh'e i tsarstvo kesaria." Put' ["The Kingdom of God and the Kingdom of Caesar." The Way] 1: 31-52.

--_. (1926). "Dnevnik filosofa. Spor o monarkhii, o burzhuasnosti i o svobode mysli." Put' ["Diary of a Philosopher: Debates on Monarchy, the Bourgeois Spirit and Freedom of Thought." The Way] 4: 176-82.

Bodin, Per-Arne. (2009). Language, Canonization and Holy Foolishness: Studies in PostSoviet Russian Culture and the Orthodox Tradition. Stockholm: Acta Universitatis Stockholmiensis.

Bulgakov, Sergei N. (1994 [1917]). Svet nevechernyi [Unfading Light]. Moscow: Respublika.

--_. (2006). "Samoderzhavie i pravoslavie.” In S. N. Bulgakov, Ot marksizma k idealizmu ["Autocracy and Orthodoxy." In From Marxism to Idealism]. Moscow: Astrel'.

-_-. (2009 [1917]). "Tserkov' i demokratiia." In Svoboda $v$ Tserkvi? Ot vymysla k istine ["The Church and Democracy." In Freedom in the Church? From Falsehood to the Truth]. Moscow. 
Celermajer, Danielle. (2009). The Sins of the Nation and the Ritual of Apologies. New York: Cambridge University Press.

Chaplin, Vsevolod. (2013, August 9). "Tserkov'-eto ne tol'ko liudi v riasakh, eto chast' nashego naroda." Ofitsial'nyi sait Moskovskoi patriarkhii ["The Church Is Not Only Men in Cassocks, It Is Part of Our People." Official Site of the Moscow Patriarchate]. [http://www.patriarchia.ru/db/text/3153975.html, accessed on August 15, 2014].

Cherniaev, Nikolai. (1998). Mistika, idealy i poeziia russkogo samoderzhaviia [The Mysticism, Ideals and Poetics of Russian Autocracy]. Moscow.

Cherniavsky, Michael. (1962). Tsar and People: Studies in Russian Myths. New Haven and London: Yale University Press.

D. Kh. [Dmitrii Khomiakov]. (1903 [1899]). Samoderzhavie [Autocracy]. Moscow.

"Dolzhen li pravoslavnyi chelovek byt' monarkhistom?" (2008). Foma ["Should an Orthodox Person Be a Monarchist?” Foma] 59(3). [http://foma.ru/dolzhen-li-pravoslavnyij-chelovek-byit-monarxistom.html, accessed on August 15, 2014].

"Eta kartina oskorbliaet patrioticheskie chuvstva russkikh liudei” (2013, October 2). Russkaia narodnaia liniia. ["This Painting Offends the Patriotic Feelings of the Russian People." The Russian People's Service].

Field, Daniel. (1976). Rebels in the Name of the Tsar. Boston: Houghton Mifflin.

Figgis, John. (1914). The Divine Right of Kings. 2nd ed. Cambridge: Cambridge University Press.

Filaret (Drozdov). (1888 [1848]). Khristianskoe uchenie o tsarskoi vlasti [The Christian Doctrine of the Tsar's Power]. Moscow.

Florenskii, Pavel. (1996 [1913]). "Okolo Khomiakova.” In P. Florenskii, Sobranie Sochinenii $v$ 4t. T. 2 ["Of and Around Khomiakov." In Collected Works in Four Volumes. Vol. 2] (278-336). Moscow.

Freeden, Michael. (1998). Ideologies and Political Theory: A Conceptual Approach. Oxford: Clarendon.

Gennadii (Belovolov). (2010, September 17). "On dal formulu nashego natsional'nogo bytiia." Russkaia narodnaia liniia ["He Gave [Us] the Formula of Our National Existence." Russian People’s Service]. [http://ruskline.ru/news_rl/2010/9/17/on_dal_ formulu_nashego_nacionalnogo_bytiya/, accessed on August 15, 2014].

Halperin, Ch. (2013). "Ivan the Terrible Returns to the Silver Screen: Pavel Lungin's Film Tsar." Studies in Russian and Soviet Cinema 7(1): 61-72.

Hedda, Jennifer. (2008). His Kingdom Come: Orthodox Pastorship and Social Activism in Revolutionary Russia. DeKalb: Northern Illinois University Press.

Hobsbawm, Eric. (1971). Primitive Rebels: Studies in Archaic Forms of Social Movement in the 19th and 2oth Centuries. 3rd ed. Manchester: Manchester University Press.

Ilarion (Alfeev). (2010) Besedy s mitropolitom Ilarionom [Conversations with Metropolitan Hilarion]. Moscow: Eksmo.

---. (2011). Tserkov' otkryta dlia kazhdogo. Vystupleniia i interv'iu [The Church is Open to Everyone: Speeches and Interviews]. Minsk: Belorusskaia Pravoslavnaia Tserkov'.

-_-. (2013, January 25). "Ilarion v programme kanala 'Soiuz." ["Hilarion [Speaks] on a Program of the TV Channel 'Soiuz”']. Soiuz TV Channel. [http://www.youtube.com/ watch?v=NR81VjumgtY, accessed on August 15, 2014].

Il'in, Ivan A. (1979). O monarkhii i respublike [Of Monarchy and Republic]. New York: Sodruzhestvo. 
Ioann (Snychev). (2011). "Samoderzhavie i Rossiia." In V. Kovalevskii (Ed.), O tsarskoi vlasti: Pamiati monakha Iony [“Autocracy and Russia." In On Autocratic Power: In Memory of Monk Iona]. St. Petersburg.

--_. (2012 [1994]). Samoderzhavie dukha: Ocherki russkogo samosoznaniia [Autocracy of the Spirit: Essays on Russian Self-Consciousness]. Moscow

Iuvenalii (Poiarkov). (2008). "Doklad mitropolita Krutitskogo i Kolomenskogo Iuvenaliia, predsedatelia Sinodal'noi komissii po kanonizatsii sviatykh." Ofitsial'nyi sait Moskovskoi patriarkhii ["Report by Metropolitan of Krutitsy and Kolomna Iuvenalii, Chair of the Synodal Commission on the Canonization of Saints." Official Site of the Moscow Patriarchate]. [http://www.patriarchia.ru/db/text/422558.html, accessed on August 15, 2014]

Kantorowicz, Ernst. (1997 [1957]). The King’s Two Bodies: A Study in Mediaeval Political Theology. Princeton, NJ: Princeton University Press.

Khoinatskii, A. (1881). Chto po preimushchestvu neobkhodimo ot nas $v$ vidu strashnykh sobytii poslednego vremeni? [What Are We to Do in Regard to the Terrible Events of Recent Years?]. Moscow: Univ. tip.

Kirill (Gundiaev). (1993). "Vozrozhdenie Pravoslaviia i obnovlenie Rossii." Zhurnal Moskovskoi patriarkhii ["The Revival of Orthodoxy and the Renewal of Russia." Journal of the Moscow Patriarchate] 9: 7-12.

---. (2007, March 27). "Mitropolit Kirill schitaet, chto nravstvennoe sostoianie rossiiskogo obshchestva iskliuchaet vosstanovlenie v strane monarkhii v blizhaishee vremia." Ofitsial'nyi sait Moskovskogo patriarkhata ["Metropolitan Kirill Thinks that the Moral Condition of Russian Society Precludes the Restoration of the Monarchy in the Country in the Near Future." Official Site of the Moscow Patriarchate]. [http:// www.patriarchia.ru/db/text/220929.html, accessed on August 15, 2014].

-_- (2008). "Doklad mitropolita Kirilla 9 iunia 2008." Ofitsial'nyi sait Moskovskogo patriarkhata ["Report by Metropolitan Kirill, June 9, 2008." Official Site of the Moscow Patriarchate]. [http://www.patriarchia.ru/db/text/422562.html, accessed on August 15, 2014].

---. (2010a). Byt' vernym Bogu [To Be Faithful to God]. Minsk: Izd. Belorus. ekzarkhata.

---. (2010b). Propovedi 2009-2010 [Sermons, 2009-2010]. Sergiev Posad: Sergieva Lavra.

--_. (2010c). "Slovo Sviateishego Patriarkha Kirilla na tseremonii podpisaniia soglasheniia o sotsial'nom partnerstve mezhdu Russkoi pravoslavnoi tserkov'iu i Ural'skim federal'nym okrugom." Zhurnal Moskovskoi patriarkhii ["His Holiness Patriarch Kirill's Speech at the Signing Ceremony for the Social Partnership Agreement between the Russian Orthodox Church and the Ural Federal District." Journal of the Moscow Patriarchate] 6: 29-31.

---. (2010d). Tserkov' prizyvaet k edinstvu: Slovo Sviateishego Patriarkha Moskovskogo i vsia Rusi Kirilla [The Church Calls for Unity: A Speech by His Holiness Patriarch of Moscow and All Russia Kirill]. Minsk: Belorusskaia pravoslavnaia tserkov'.

---. (2013). Slovo Pastyria (1991-2011). Sobranie trudov. T. 1 [A Pastor’s Words (19912011): Collected Works. Vol. 1]. Moscow.

Kitsenko, Nadezhda B. [Kizenko, Nadieszda B.] (2006). Sviatoi nashego vremeni: Otets Ioann Kronshtadtskii i russkii narod [A Saint for Our Time: Father John of Kronstadt and the Russian People]. Moscow: Novoe literaturnoe obozrenie.

Klykov, V. M. (1996). "Istinnyi svet monarkhii." Zavtra ["The True Light of Monarchy." Tomorrow] 16. 
Kolonitskii, Boris. I. (2010). "Tragicheskaia erotika": Obrazy imperatorskoi sem’i v gody Pervoi mirovoi voiny ["Tragic Eroticism": Images of the Imperial Family During the First World War]. Moscow: Novoe literaturnoe obozrenie.

Korkunov, N. M. (1892-1893). Russkoe gosudarstvennoe pravo. 2 T. T. 1 [Russian State Law. 2 vol. Vol. 1]. St. Petersburg: Tip. M. M. Stasiulevicha.

Koshelev, A. I. (1862). Konstitutsiia, samoderzhavie i zemskaia duma [The Constitution, Autocracy and the Land Assembly]. Leipzig: F. Vagner.

Kostiuk, Konstantin N. (2013). Istoriia sotsial'no-eticheskoi mysli $v$ Russkoi pravoslavnoi tserkvi [The History of Social and Ethical Thought in the Russian Orthodox Church]. St. Petersburg: Aleteiia.

Kovalevskii, V. (2011). "Vstuplenie." In V. Kovalevskii (Ed.), O tsarskoi vlasti: Pamiati monakha Iony [“Introduction." In V. Kovalevskii (Ed.), On Autocratic Power: In Memory of Monk Iona]. St. Petersburg.

Krylov, A. (2013, July 15). "Nasledniki Lzhedmitriia." Rossiiskie vesti ["Heirs of the False Dmitrii." Russian News] no. 14-15.

Kuraev, Andrei V. (2009a, November 9). "Tsar” ["The Tsar"]. Live Journal of Andrei Kuraev. [http://diak-kuraev.livejournal.com/2009/11/o9/, accessed on August 15, 2014].

---. (2009b). Tserkov'v mire liudei. 5-e izd. [The Church in the World of the People. $5^{\text {th }}$ ed.]. Moscow: Izd-vo Sretenskogo monastyria.

"K voprosu o kanonizatsii tsaria Ivana Groznogo i G. E. Rasputina. Prilozhenie No. 2 k dokladu mitropolita Krutitskogo i Kolomenskogo Iuvenaliia.” (2008, June 7). Ofitsial'nyi sait Moskovskogo patriarkhata ["On the Question of the Canonization of Tsar Ivan the Terrible and G. E. Rasputin. Appendix No. 2 to the Report by Metropolitan Iuvenal of Krutitsky and Kolomna." Official Site of the Moscow Patriarchate]. [http://www.patriarchia.ru/db/text/420877.html, accessed on August 15, 2014].

Lopukhin, A. P. (1915). Bibleiskaia istoriia $v$ svete noveishikh issledovanii i otkrytii: Vetkhii Zavet. Izd. 2-e. T. 4 [Biblical History in Light of the Newest Research and Discoveries: Old Testament. 2nd ed. Vol. 4]. Petrograd [St. Petersburg].

Luk'ianov, M. N. (2006). Rossiiskii konservatizm i reforma, 1907-1914 [Russian Conservatism and Reform, 1907-1914]. Stuttgart: Ibidem-Verlag.

Malashenko, A. V., and Filatov, S. B. (2012). Pravoslavnaia tserkov' pri novom patriarkhe [The Orthodox Church under the New Patriarch]. Moscow: ROSSPEN.

Maler, Arkadii. (2012, March 7). "Pravoslavie ne ogranicheno monarkhiei." NG-Religii [“Orthodoxy (Cannot Be) Reduced to Monarchy." Independent Gazette-Religion Section]. [http://www.ng.ru/ng_religii/2012-03-07/5_pravoslavie.html, accessed on August 15, 2014].

“'Monarkhiia-nailuchshii, ideal'nyi obraz pravleniia.' Pravoslavnye sviashchennosluzhiteli o monarkhicheskoi idee." (2012, March 15). Russkaia narodnaia liniia [“"Monarchy is the best, the ideal form of government.' Orthodox Clergy on the Monarchist Idea." The Russian People's Service] [http://ruskline.ru/news_rl/2012/o3/15/ monarhiya_nailuchshij_idealnyj_obraz_pravleniya/, accessed on June 10, 2016].

“Monarkhiia v Rossii: Proidennyi etap?” (2013, March 19). Sait VTsIOM [“Monarchy in Russia: A Closed Chapter?" Website of the Russian Public Opinion Research Center]. [http://wciom.ru/index.php?id=459\&uid=113775, accessed on August 15, 2014].

Morozov, A. (2000). “Novyi kurs' i Moskovskaia Patriarkhiia.” NG-Religii [“"The New Course' and the Moscow Patriarchate." Independent Gazette-Religion Section] 62(15). 
Neviarovich, Vladimir K. (2004). Blagoslovenno tsarstvo: Tserkovnye osnovy monarkhicheskoi idei $v$ Rossii [Blessed Be Thy Kingdom: The Religious Foundations of the Monarchist Idea in Russia]. St. Petersburg.

"O chine pravoslaviia." Sait Khrama Khista Spasitelia ["On the Orthodox Rite." Website of the Church of Christ the Savior]. [http://www.xxc.ru/orthodox/pastor/torgestvo/ index.htm, accessed on August 15, 2014].

“Osnovy sotsial'noi kontseptsii Russkoi Pravoslavnoi Tserkvi." (200o). Ofitsial'nyi sait Moskovskogo patriarkhata ["The Bases of the Social Conception of the Russian Orthodox Church." Official Site of the Moscow Patriarchate] [http://www.patriarchia.ru/ $\mathrm{db} / \mathrm{text} / 141422]$.

"O vzaimootnosheniiakh Tserkvi s gosudarstvom i svetskim obshchestvom na kanonicheskoi territorii Moskovskogo patriarkhata." (1994). Ofitsial'nyi sait Moskovskogo patriarkhata ["On the Church's Interactions with the State and Secular Society on the Canonical Territory of the Moscow Patriarchate." Official Site of the Moscow Patriarchate]. [http://sobor.patriarchia.ru/db/text/53046o.html, accessed on August 15, 2014]

Paromov, K. (2011). “'Okolo Khomiakova' o. P. A. Florenskogo i starshie slavianofily: V popytke oboznachit' svoeobrazie tsarskoi vlasti." Vestnik PSTGU. Istoriia [“Fr. P. A. Florensky's 'Of and Around Khomiakov' and the Major Slavophiles: An Attempt to Delineate the Distinctiveness of the Tsar's Power." Herald of the Orthodox St. Tikhon Humanities University: History] (38)1: 23-48.

Petrov, A. (1926). "Pis'mo monarkhista v redaktsiiu zhurnala 'Put'."' Put' [“A Letter from a Monarchist to the Editor of the Journal 'Put'." The Way] 3: 134-44.

Richters, Katja. (2013). The Post-Soviet Russian Orthodox Church: Politics, Culture, and Greater Russia. London and New York: Routledge.

Rozanov, Vasilii V. (1912). O podrazumevaemom smysle nashei monarkhii [On the Implied Meaning of Our Monarchy]. St. Petersburg.

Russkaia Tserkov' na rubezhe vekov. (2001). [The Russian Church at the Turn of the Century]. St. Petersburg.

"Russkie monarkhisty-kto oni?” (1996, October 17). Russkaia mysl' ["Russian MonarchistsWho Are They?" Russian Thought].

Russkii chas. (2009, June 23). TV programma [The Russian Hour. TV program].

Semenko, V. (2001). "Kogo Bog khochet pogubit', togo on lishaet razuma." Radonezh ["Those Whom God Wishes to Destroy He First Makes Mad." Radonezh] 2000, № 9. In Russkaia tserkov' na rubezhe vekov [The Russian Church at the Turn of the Century]. St. Petersburg.

Serafim (Sobolev). (2002). Ob istinnom monarkhicheskom mirosozertsanii [On the True Monarchist Worldview]. Moscow: Lestvitsa.

Serafim (Sobolev), Filaret (Drozdov), and Ioann (Maksimovich). (200o). Russkaia ideologiia [Russian Ideology]. Moscow: Lestvitsa.

Sharapov, S. F. (1902). Cherez polveka [Fifty Years from Now]. Moscow.

---. (1905). Opyt russkoi politicheskoi programmy [An Exercise on the Russian Political Program]. Moscow.

-_-. (1907). [Peredovaia stat'ia] Russkoe delo [Lead Article. Russian Affairs] 1: 1-4.

Skinner, Quentin. (1969). "Meaning and Understanding in the History of Ideas." History and Theory 8(1): 3-53.

---. (2002). Visions of Politics: Regarding Method. Vol. 1. Cambridge: Cambridge University Press. 
Slater, Wendy. (2005). "Relics, Remains, and Revisionism: Narratives of Nicholas II in Contemporary Russia." Rethinking History: The Journal of History and Practice 9(1): $53-70$.

"Slavianofil'stvo i zapadnichestvo: Konservativnaia i liberal'naia utopiia v rabotakh Andzheia Valitskogo." (1991) In Referativnyi sbornik. Vyp. 2 ["Slavophilism and Westernism: Conservative and Liberal Utopias in the Works of Andzhei Valitskii." In Collected Abstracts. Issue 2]. Moscow: INION.

Solonevich, Ivan. (1991). Narodnaia monarkhiia [People's Monarchy]. Moscow: Feniks.

Solzhenitsyn, Aleksandr I. (1995 [1973]). "Raskaianie i samoogranichenie kak kategorii natsional'noi zhizni." In A. I. Solzhenitsyn, Publitsistika. T. 1 [“Repentance and SelfLimitation as Aspects of National Life." In A. I. Solzhenitsyn, Journalistic Writings. Vol. 1] 49-86. Yaroslavl: Verkhne-Volzhskogo knizhnoe izd-vo.

Staats, Reinhart. (1976). Theologie der Reichskrone: Ottonische "renovatio imperii" im Spiegel einer Insignie. Stuttgart: Hiersemann.

Sverdlov, D. (2012, March 21). "Samoderzhavie-vozhdelennaia illiuziia." NG-Religii ["Autocracy Is a Longed-For Illusion." Independent Gazette-Religion Section] 300 (5).

"Svetskaia konstitutsionnaia monarkhiia dlia Pravoslaviia dukhovno nepriemlema." (2011, May 11). Russkaia narodnaia liniia " ["Secular Constitutional Monarchy Is Spiritually Unacceptable for Orthodoxy." The Russian People's Service]. [http://ruskline. ru/news_rl/2011/o5/11/svetskaya_konstitucionnaya_monarhiya_dlya_pravoslaviya_duhovno_nepriemlema/, accessed on August 15, 2014].

"Sviashchennosluzhiteli o monarkhicheskoi idee." (2012, March 15). Informatsionnoe agentstvo Regions.ru ["Clergy on the Monarchist Idea." Information agency Regions.ru]. [http://regions/ru/news/2398676, accessed on August 15, 2014].

Tikhomirov, L. A. (1905). Monarkhicheskaia gosudarstvennost'. 4 ch. Ch. 4 [Monarchist Statehood. 4 parts. Part 4]. Moscow: Univ. tip.

Trubetskoi, Grigorii. (1926). "Spor o monarkhii." Put' ["Debate on Monarchy." The Way] 4: 72-75.

Turunen, Maija. (2007). "Orthodox Monarchism in Russia: Is Religion Important in the Present-Day Construction of National Identity?" Religion, State and Society 35(4): $319-34$

Vasil'ev, A. V. (1883). Zadachi i stremleniia slavianofil'stva [The Tasks and Aspirations of Slavophilism]. St. Petersburg.

---. (1890). [Peredovaia stat'ia]. Blagovest [(Lead Article.) The Church Bell] 3.

Veniamin (Valerii Novik). (1999). Pravoslavie. Khristianstvo. Demokratiia [Orthodoxy. Christianity. Democracy]. St. Petersburg.

Vereshchagin, V. Iu., Makeev, V. V., and Ponezhin, M. Iu. (2003). Doktrina monarkhicheskoi gosudarstvennosti L. A. Tikhomirova [The Doctrine of Monarchist Statehood by L. A. Tikhomirov]. Rostov-on-Don: Rostovskii iuridicheskii institut.

"V Moskve uchrezhdena Monarkhicheskaia partiia Rossii." (2012, April 7). Moskovskie novosti ["In Moscow the Monarchist Party of Russia is Founded." Moscow News].

Vostorgov, Ioann I. (1995). "Monarkhicheskii katekhizis." In Ioann Vostorgov, Polnoe sobranie sochinenii v 5 T. T. 4 ["The Monarchist Catechesis." In Complete Collected Works in Five Volumes. Vol. 4]. St. Petersburg: Tsarskoe delo.

---. (2011). "Smysl tsarskogo koronovaniia." In V. Kovalevskii (Ed.), O tsarskoi vlasti: Pamiati monakha Iony ["The Meaning of the Tsar's Coronation." In On Autocratic Power: In Memory of Monk Iona]. St. Petersburg.

Zaitsev, Kirill I. (2010). Vernut'sia $v$ Rossiiu: Izbrannye stat'i, 1923-1968 [Returning to Russia: Selected Articles, 1923-1968]. Moscow. 
Zernov, Igor'. (2007) Ivan Il'in: Monarkhiia i budushchee Rossii [Ivan Il'in: Monarchy and Russia's Future]. Moscow: Algoritm.

Zhivov, V. M., and B. A. Uspenskii. (1987). "Tsar' i bog: Semioticheskie aspekty sakralizatsii monarkhii v Rossii." In B. A. Uspenskii (Ed.), Iazyki kul'tury i problemy perevodimosti ["The Tsar and God: Semiotic Aspects of the Sacralization of Monarchy in Russia." In Languages of Culture and Problems of Translatability]. Moscow: Nauka. 